\title{
Occurrence and Identification of Phytophthora spp. Pathogenic to Pear Fruit in Irrigation Water in the Wenatchee River Valley of Washington State
}

\author{
F. Yamak, T. L. Peever, G. G. Grove, and R. J. Boal
}

First and third authors: Washington State University Irrigated Agriculture Research and Extension Center, 24106 N. Bunn Road, Prosser 99350; second author: Department of Plant Pathology, Washington State University, Pullman 99164; and fourth author: Washington State University Tree Fruit Research and Extension Center, 1100 N. Western Avenue, Wenatchee 98801. Accepted for publication 21 June 2002.

\begin{abstract}
Yamak, F., Peever, T. L., Grove, G. G., and Boal, R. J. 2002. Occurrence and identification of Phytophthora spp. pathogenic to pear fruit in irrigation water in the Wenatchee River Valley of Washington State. Phytopathology 92:1210-1217.

Seven hundred forty-nine isolates of Phytophthora spp. were obtained from irrigation canals in eastern Washington State during the 1992 to 1995 and 1999 growing seasons. Isolates were retrieved using pear baiting techniques. All isolates were pathogenic to pear and were present in irrigation water beginning early in fruit development. Over the course of the 5 year study, 10 and $5 \%$ of isolates were identified as P. cactorum and $P$. citricola, respectively, using morphological criteria. The remaining isolates could not be identified using morphological criteria. Colony morphology of these isolates was characterized during all years of the study. In 1999, more detailed studies utilizing polymerase chain reaction restriction fragment length polymorphism (PCR-RFLP) analysis of entire internal transcribed spacer (ITS) regions (ITS1, 5.8S, and ITS2) of ribosomal DNA for 180 isolates, and sequence analysis of ITS2 for 50 isolates, were used to investigate genetic variation and phylogenetic
\end{abstract}

ABSTRACT

Phytophthora is a cosmopolitan genus comprised of 67 described species and varieties, many of which are economically important plant pathogens $(14,38)$. Sprinkler rot of apple (Malus domestica Borkh.) and pear (Pyrus communis L.), which is reportedly caused by Phytophthora cactorum (Lebert \& Cohn), was previously considered an occasional pathogen of apple and pear fruit, but has become widespread and common in the Wenatchee River Valley of Washington State $(9,22)$. The disease is characterized by firm chocolate-brown lesions that may cover the fruit surface after several days. Pears are susceptible beginning early in fruit development, whereas the susceptibility of apple fruits increases as fruit matures (22). Irrigation water is also frequently contaminated with the pathogen and the disease is prevalent in orchards using over-the-canopy irrigation or when the sprinkler angles of under-the-canopy systems are sufficiently high to moisten fruit $(9,22)$.

$P$. cactorum has been reported as the primary incitant of sprinkler rot of apple and pear $(9,22)$ and was the predominant species isolated from infected fruit and irrigation water during previous studies in the Wenatchee River Valley $(22,24)$. However, $P$. citricola Sawada, P. cambivora (Petri) Buisman, and unidentified nonpapillate species were also occasionally isolated from in-

Corresponding author: G. G. Grove; E-mail address: grove@wsu.edu

Publication no. P-2002-0918-01R

(C) 2002 The American Phytopathological Society relationships among isolates. Isolates were divided into 12 groups based on their growth type on corn meal agar. Restriction digestion of the entire ITS region with three enzymes revealed 11 restriction digestion patterns among 180 isolates. PCR-RFLP and sequence data were obtained for 12 reference Phytophthora spp. (two species in each of Waterhouse's six morphological groups). Phylogenetic analysis of ITS2 regions revealed nine clades, each with strong bootstrap support. Molecular analyses revealed 23 isolates that were in the $P$. gonapodyides clade, 9 in the $P$. parasitica clade, 1 in the $P$. cactorum clade, 7 in the $P$. citricola/capsici clade, and 4 in the $P$. cambivora/pseudotsugae clade. The three isolates comprising clade 5 were significantly distinct from all other Phytophthora spp. in the databases and may represent a new Phytophthora sp. Colony morphology was not consistently correlated to PCR-RFLP pattern or ITS2 phylogeny, suggesting that the former criterion is insufficient for species identification. The results of this study indicate that at least nine phylogenetically distinct taxa of Phytophthora pathogenic to pear are present in irrigation water in North Central Washington.

Additional keywords: systematics, water quality.

fected fruit and contaminated irrigation water during subsequent epidemics (G. G. Grove, unpublished data). The latter comprised the vast majority of isolates retrieved from irrigation water.

Copper is routinely added to irrigation water in order to manage sprinkler rot. Growers in Washington currently begin treatments when immature pears suspended in irrigation canals become infected. During some years, this approach fails to provide adequate warning of the presence of pathogenic species in irrigation water. Earlier studies showed that Phytophthora spp. retrieved from irrigation water vary in their sensitivity to copper (G. G. Grove, unpublished data), which complicates management decisions faced by the producer. If excessive copper is added, damage to developing fruit may occur, whereas insufficient copper may preclude effective disease management. Therefore, the accurate identification and initial occurrence of Phytophthora spp. present in irrigation water during the period of fruit susceptibility is required for determining the optimum concentration and timing of copper injections. Knowledge of the initial occurrence, frequency, and copper sensitivity of Phytophthora spp. in irrigation water could facilitate disease management by improving the timing and rates of copper applications.

The identification of Phytophthora spp. has been traditionally based on sporangial, oogonial, antheridial, and colony morphology $(2,13,38)$. A tabular key has been devised to divide the genus into six groups based on morphological characters $(13,41,44)$. However, these characters can be inconsistent and are sometimes difficult to assess. Morphological characters tend to overlap be- 
tween species and it is often difficult to induce sporulation in vitro $(13,31,38)$. As a result, Phytophthora spp. have been frequently unidentified or misidentified. To overcome this problem, molecular analyses have been used for identification, genetic and epidemiological studies, and examination of evolutionary relationships within Phytophthora and closely related genera $(1,4-8,10-12,15$, $16,19,20,21,23,25-27,32,33,39)$.

Intraspecific variation in Phytophthora an other fungi has been assessed using random amplified polymorphic DNA analysis (5, 28), random amplified microsatellites (23), and restriction fragment length polymorphism (RFLP) in nuclear and mitochondrial DNA (15-18). In most cases, isozyme analysis has been inadequate for studying intraspecific variation in the genus (16,19,31-33), although it has been used for analyzing interspecific hybrids (26). RFLP and sequence analysis of the internal transcribed spacer (ITS) region of ribosomal DNA (rDNA) have been used to investigate relationships among Waterhouse's six morphological groups $(6,7,9)$. The ITS region has a mutation rate that is appropriate for examination of evolutionary relationships at the species level in the genus (11). The objectives of this study were (i) to determine the seasonal occurrence and frequency of Phytophthora spp. that are pathogenic to pear and present in irrigation canals, and (ii) to use morphological characteristics, polymerase chain reaction (PCR)-RFLP, and sequence analyses of rDNA ITS to identify Phytophthora spp. pathogenic to pear and present in irrigation water.

\section{MATERIALS AND METHODS}

Sampling of irrigation water. Isolates were retrieved from irrigation water by regularly sampling canals within a $15-\mathrm{km}$ radius of Wenatchee, WA, during April to September 1992 to 1995 and May to August 1999. Ten, five, and four canals were sampled in 1992 to 1994, 1995, and 1999, respectively. Immature pear fruits were either (i) suspended in jars containing irrigation water (in the laboratory) or (ii) suspended in pots that were placed into irrigation canals according to previously described methods (22, 24). When using the former technique during 1992 to 1995, irrigation water was collected weekly or biweekly in 1.1-liter glass jars and transported to the laboratory. One mature pear (cv. Bartlett) was suspended in the water for 3 days at 20 to $25^{\circ} \mathrm{C}$ in continuous light. To maximize the number of Phytophthora isolates collected in 1999, different incubation conditions were employed when using this technique. Samples were collected at 4- to 7-day intervals. On each sampling date, four water samples were collected from each canal with 1.1-liter canning jars. One mature pear (cv. Bartlett) was suspended in water for 3 days in either $24 \mathrm{~h}$ continuous light or $24 \mathrm{~h}$ continuous dark at $10^{\circ} \mathrm{C}$ or at room temperature (between 20 to $25^{\circ} \mathrm{C}$ ). At the end of the incubation period, pears were rinsed with distilled water and incubated for 2 to 4 days at room temperature $\left(20\right.$ to $25^{\circ} \mathrm{C}$ ) in continuous light.

Isolation and culture preparation. Infected pears were rinsed with $95 \% \mathrm{EtOH}$, and isolations were performed by sampling tissue from lesion edges. Tissue was incubated on pentachloronitrobenzene-benomyl-neomycin sulfate-chloramphenicol-selective medium (40) at room temperature $\left(20\right.$ to $\left.25^{\circ} \mathrm{C}\right)$. When mycelia emerged from the edge of 3- to 5-day-old cultures, hyphal tips were transferred to V8 agar to obtain pure cultures (30). A total of 749 isolates were obtained. Pure cultures were stored in glass tubes $(21 \times 73 \mathrm{~mm})$ containing $7 \mathrm{ml}$ of lima bean agar (38). For long-term storage, isolates were covered with sterile mineral oil (47) (Sigma Chemical, St. Louis) after 3 to 5 days growth.

Pathogenicity and lesion type. Inoculations were performed to determine pathogenicity and investigate variability in lesion morphology. Isolates were grown on V8-juice agar medium at room temperature for 3 days. Immediately prior to inoculation, pear fruits were wounded with a flame-disinfested 4-mm-diameter cork borer. Each isolate was placed into two wounded pears ('D'Anjou' or 'Bartlett', which are equally susceptible) (22). Mycelia from culture edges were placed in the wounds, covered with Parafilm, and incubated at 20 to $22^{\circ} \mathrm{C}$ for 3 to 4 days. Following incubation, the color, size, and margin characteristics of each lesion was recorded.

Morphological characterization. Isolates were transferred to various media to promote the production of oospores and sporangia $(31,38,49)$ necessary for morphological characterization. Mycelial disks, $4 \mathrm{~mm}$ in diameter, were removed from cultures growing on V8 medium with a cork borer. Disks were transferred to lima bean agar, V8-juice agar, or soil extract (3) to stimulate the formation of sporangia. Soil extract was prepared by suspending $15 \mathrm{~g}$ of soil in 1 liter of distilled water for $12 \mathrm{~h}$ (3). Soil suspensions were then centrifuged in 40-ml plastic tubes in a centrifuge (Beckman J2-21; Beckman Inc., Redmond, WA) at 10,000 $\times \mathrm{g}$ for $25 \mathrm{~min}$ and the aqueous phase was transferred to 250-ml widemouth bottles (Nalgene Inc., Rochester, NY). Morphological characterization of oospores and sporangia was based on the method of Stamps et al. (41).

To observe colony morphology, isolates grown on V8 agar were transferred to corn meal agar (CMA) (31). Four replicate plates were inoculated with each isolate, sealed with Parafilm, and inverted. Two of the replicate plates were incubated at 20 to $25^{\circ} \mathrm{C}$, and two replicate plates were incubated at $20^{\circ} \mathrm{C}$ in a 12 -h photoperiod. Colony morphology on CMA was recorded after 7 days (44-46).

Reference species. Two reference species were chosen from each of Waterhouse's six morphological groups (41). Reference isolates were obtained from cooperators for molecular comparison with the isolates (Table 1) from irrigation water. Because they have been reported as pathogenic to apple, pear, or both fruits (38), P. cactorum, P. cinnamomi Rands, $P$. gonapodyides (Petersen) Buisman, P. palmivora (E. J. Butler), P. citricola, and $P$. parasitica Dastur were included in this study (Table 1). In addition to live cultures of reference species, ITS2 sequence data was obtained from GenBank for $P$. cambivora and $P$. citricola.

Mycelium production. After sufficient colony growth on V8 agar, mycelia were scraped from the agar surface and transferred to $250-\mathrm{ml}$ flasks containing $120 \mathrm{ml}$ of lima bean broth amended with $10 \mu \mathrm{g} / \mathrm{ml}$ of chloramphenicol (Sigma Chemical). Twenty-five to thirty disks cut from the culture margins were used for inoculation. Cultures were incubated on an orbital shaker at $190 \mathrm{rpm}$ for 7 to 10 days at 20 to $25^{\circ} \mathrm{C}$. Mycelia were vacuum-filtered through Whatman No. 1 filter paper (Whatman, Maidstone, UK), placed in $2-\mathrm{ml}$ microcentrifuge tubes, and frozen at $-20^{\circ} \mathrm{C}$ for $2 \mathrm{~h}$. Frozen mycelia were lyophilized, ground with a metal rod, and stored dry at $-20^{\circ} \mathrm{C}$ for subsequent DNA extraction.

Genomic DNA extraction. Genomic DNA was extracted from $50 \mu \mathrm{g}$ of lyophilized mycelia as described by Peever et al. (35) with modifications. Supernatant collected following potassium acetate precipitation was subjected to phenol/chloroform/isoamyl alcohol (25:24:1, vol/vol/vol) extraction followed by chloroform/ isoamyl alcohol $(24: 1, \mathrm{vol} / \mathrm{vol})$ extraction. DNA pellets were resuspended in sterile distilled water, and DNA concentrations were estimated visually in ethidium bromide-stained agarose gels $(0.7 \%)$ by comparing band intensity with known quantities of HindIII-digested phage lambda DNA (Promega, Madison, WI). DNAs were routinely diluted to $50 \mathrm{ng} / \mu \mathrm{l}$ for PCR amplification.

PCR amplification and restriction digestion of rDNA ITS. Entire ITS regions encompassing ITS1, 5.8S, and ITS2 regions of nuclear rDNA were amplified and digested with restriction enzymes for PCR-RFLP analysis. ITS1 (5'- TCCGTAGGTGAACCTGCGG) and ITS4 (5'-TCCTCCGCTTATTGATATGC) universal primers were used to amplify the entire ITS region (48). PCR was performed in $50-\mu 1$ reaction volumes with each reaction mixture containing $5 \mu \mathrm{l}$ of $10 \times$ PCR buffer, $1 \mathrm{mM} \mathrm{MgCl} 2$ (Promega), $20 \mu \mathrm{M}$ deoxynucleoside triphosphates (Idaho Technologies, Idaho Falls, ID), $1 \mu \mathrm{M}$ ITS1 and ITS4 primers, 2 units of Taq DNA 
polymerase (Promega), and $50 \mathrm{ng}$ of genomic DNA. This and all subsequent PCR amplifications were performed in a thermocycler (Hybaid Omne-E; Hybaid Ltd., Middlesex, UK). Cycling conditions included an initial $5 \mathrm{~min}$ denaturation at $96^{\circ} \mathrm{C}$ followed by 35 cycles of $96^{\circ} \mathrm{C}$ for $1 \mathrm{~min}$ (melt), $60^{\circ} \mathrm{C}$ for $1 \mathrm{~min}$ (anneal), and $72^{\circ} \mathrm{C}$ for $1 \mathrm{~min}$ (extension). The final extension cycle was $72^{\circ} \mathrm{C}$ for $10 \mathrm{~min}$. PCR products were separated in $1.2 \%$ agarose gels (69 V for $5 \mathrm{~h}$ ) with HindIII/EcoRI-digested lambda DNA (Promega) as a size standard, and visualized using a digital imaging system (UVP, Upland, CA). Amplicons obtained using ITS1 and ITS4 primers were digested with three different four-base-cutting restriction enzymes: HaeIII (GG/CC), RsaI (GT/AC), and MspI (C/CGG) (Life Technologies, Grand Island, NY). Restriction digestions were performed in $10-\mu 1$ reaction volumes containing $3.7 \mu \mathrm{l}$ of sterile distilled water, $1 \mu \mathrm{l}$ of reaction buffer, 3 units of restriction enzyme, and $150 \mathrm{ng}$ of PCR product. Digested ITS amplicons were separated on $2 \%$ agarose gels ( $92 \mathrm{~V}$ for $150 \mathrm{~min}$ ) with HindIII/EcoRI-digested lambda DNA (Promega) as a size standard and visualized using the digital imaging system described previously.

Analysis of ITS PCR-RFLP data. The presence or absence of restriction fragments obtained with three different restriction enzymes was scored for each isolate. Each isolate was treated as the operational taxonomic unit, and only isolates with unique PCRRFLP haplotypes were included in the analysis. A distance phenogram was constructed with the RESTDIST, NEIGHBOR, and CONSENSE programs in PHYLIP (Phylogeny Inference Package; J. Felsenstein, 1993. version 3.5c, Department of Genetics, University of Washington, Seattle). A distance matrix was estimated using the program RESTDIST, and distances were clustered using neighbor joining in the program NEIGHBOR. A majority-rule consensus tree was generated using CONSENSE, and statistical support for phenogram branches was estimated with 1,000 bootstrapped data sets generated by the program SEQBOOT. The program TREEVIEW (34) was used to visualize the phenogram.

Amplification and sequencing of ITS2. Isolates with different ITS PCR-RFLP patterns and one isolate of each reference species were further characterized by sequencing the ITS2 region and using distance analysis to estimate a phylogeny. At least one representative isolate with each PCR-RFLP pattern was chosen for sequencing. ITS2 regions of the sampled isolates were amplified using ITS3 (5'- GCATCGATGAAGAACGCAGC) and ITS4 universal primers (5'-TCCTCCGCTTATTGATATGC) (48). PCR reactions were conducted in 50- $\mu$ reaction volumes composed of $10 \times$ PCR buffer (Promega), $1 \mathrm{mM} \mathrm{MgCl}$ (Promega), $20 \mu \mathrm{M}$ deoxynucleoside triphosphate (Idaho Technologies), $0.25 \mu \mathrm{M}$ ITS3 and ITS4 primers, 2 units of Taq DNA polymerase (Promega), and $50 \mathrm{ng}$ of DNA template. An initial denaturation step was performed for $2 \mathrm{~min}$ at $95^{\circ} \mathrm{C}$ followed by 30 cycles of denaturation at $95^{\circ} \mathrm{C}$ for $30 \mathrm{~s}$, annealing at $60^{\circ} \mathrm{C}$ for $30 \mathrm{~s}$, extension at $72^{\circ} \mathrm{C}$ for $30 \mathrm{~s}$, and a $10 \mathrm{~min}$ final extension step at $72^{\circ} \mathrm{C}$. ITS2 amplicons were purified with PCR purification spin columns (QiaQuick; Qiagen, Valencia, CA) following the manufacturer's directions. Purified PCR products were separated on ethidium bromide-stained $0.7 \%$ agarose gels, and DNA concentrations were estimated based on the intensity of the PCR product relative to HindIII-digested lambda DNA (Promega). Column-purified ITS2 amplicons were direct-sequenced on both strands using ITS3 and ITS4 primers. Each sequence reaction contained 40 to $90 \mathrm{ng}$ of DNA, $320 \mathrm{nM}$ primer, $4 \mu \mathrm{l}$ of sequence reaction mix (BigDye Terminator Cycle Sequencing Ready Reaction Mix; Applied Biosystems, Foster City, CA), and sterile distilled water in 10- $\mu$ l volumes. Cycling conditions consisted of 25 cycles of $15 \mathrm{~s}$ at $96^{\circ} \mathrm{C}, 15 \mathrm{~s}$ at $50^{\circ} \mathrm{C}$, and $4 \mathrm{~min}$ at $60^{\circ} \mathrm{C}$. Sequence products were purified with gel filtration cartridges (Centriflex; Edge BioSystems, Gaithersburg, MD), and sequenced on an automated DNA sequencer (PE Biosystems Model 377; Applera Corporation, Norwalk, CT). Sequencing was performed in the Laboratory for Biotechnology and Bioanalysis, School of Molecular Biosciences, Washington State University, Pullman.

Sequence alignment and phylogenetic analysis. To determine the phylogenetic relationships of sampled isolates and their relationships to the reference species, ITS2 regions were aligned and phylogenetic analysis was performed. Some isolates shared identical ITS2 sequences and duplicate sequences were removed from the data set prior to phylogenetic analysis. Isolates from irrigation water and reference species were sequenced, and ITS2 sequences were obtained from GenBank. One isolate of each reference species was sequenced and included in the phylogenetic analysis, except two $P$. cactorum and $P$. infestans isolates were sequenced. The two $P$. cactorum isolates retrieved from irrigation water were included in the phylogenetic analysis because they had different colony morphologies. A P. cambivora isolate retrieved from a naturally infected pear and a $P$. citricola isolate obtained from irrigation water were also included. Two $P$. cambivora sequences (GenBank Accession Nos. AF266763 and AF139369) and a $P$. citricola isolate (GenBank Accession No. AF266788) were obtained and included in the phylogenetic analysis. Sequences were aligned using Clustal-X (42), and the unrooted phylogeny was estimated by distance analysis in PHYLIP. One thousand bootstrapped data sets were generated using SEQBOOT and fed into DNADIST to compute a distance matrix with the Kimura 2-parameter nucleotide substitution model with a transition/transversion ratio of 2.2 estimated from the data set. Distances were clustered using neighbor joining in the program NEIGHBOR with random input order of taxa, and the consensus phylogram was constructed using CONSENSE. Branch lengths were estimated by maximum likelihood in the program DNAML

TABLE 1. Reference Phytophthora spp.

\begin{tabular}{|c|c|c|}
\hline Species & Source & Waterhouse group \\
\hline P. cactorum 1 (Lebert \& Cohn) Schröter & G. G. Grove, Washington State University & I \\
\hline P. cactorum 2 (Lebert \& Cohn) Schröter & G. G. Grove, Washington State University & I \\
\hline P. pseudotsugae Hamm \& Hansen & E. M. Hansen, Oregon State University & I \\
\hline P. palmivora (E. J. Butler) (A1 mating type) & J. E. Adaskaveg, University of California, Riverside & II \\
\hline P. capsici Leonian & J. B. Ristaino, North Carolina State University & II \\
\hline P. parasitica 1 Dastur & J. B. Ristaino, North Carolina State University & III \\
\hline P. parasitica 2 Dastur & J. B. Ristaino, North Carolina State University & III \\
\hline P. citricola Sawada & G. G. Grove, Washington State University & III \\
\hline P. infestans (Mont.) de Bary (US1) & D. A. Johnson, Washington State University & IV \\
\hline P. infestans (US11) & D. A. Johnson, Washington State University & IV \\
\hline P. mirabilis Galindo \& Hohl (A1) & J. E. Adaskaveg, University of California, Riverside & IV \\
\hline P. megasperma 1 (Drechs.) & G. G. Grove, Washington State University & $\mathrm{V}$ \\
\hline P. megasperma 2 (Drechs.) & G. G. Grove, Washington State University & V \\
\hline P. lateralis Tucker \& Milbrath & E. M. Hansen, Oregon State University & $\mathrm{V}$ \\
\hline P. cinnamomi 1 Rands & G. G. Grove, Washington State University & VI \\
\hline P. cinnamomi 2 Rands & G. G. Grove, Washington State University & VI \\
\hline P. gonapodyides (Petersen) Buisman & E. M. Hansen, Oregon State University & VI \\
\hline
\end{tabular}


with the distance tree as the user tree. Statistical support for phylogram branches was estimated by bootstrapping with 1,000 bootstrapped data sets. The program TREEVIEW (34) was used to visualize the phylogram.

\section{RESULTS}

Seasonal occurrence, pathogenicity, and lesion types. Seven hundred forty-nine isolates were retrieved from irrigation water using direct and indirect baiting methods. All isolates were pathogenic to pear in subsequent inoculations. The initial detection of $P$. cactorum occurred on 29, 28, 28, and 9 May 1992, 1993, 1994, and 1995, respectively. P. citricola was first detected on 1 July, 4 June, 24 June, 9 July, and 16 July 1992, 1993, 1994, 1995, and 1999 , respectively. Nonpapillate isolates were first detected on 22 May, 7 May, 22 April, 17 April, and 8 June 1992, 1993, 1994, 1995 , and 1999, respectively. The proportion of canals infested and relative proportions of isolates classified as $P$. cactorum, $P$. citricola, or unidentified nonpapillate isolates are presented in Figure 1. These latter isolates were detected in all canals sampled during all years of the study. Baiting in jars was somewhat more efficient for detection of the nonpapillate isolates. In one canal, $64.3,63.6$, and $72.2 \%$ of the nonpapillate, unidentified isolates were detected by this technique in 1992, 1993, and 1994, respectively. Based on color, homogeneity of color, size, and distinction of lesion margin as criteria, eight different lesion types were observed (data not shown). Lesion types that developed on artificially inoculated pears were frequently different from lesion types observed on the original bait pears. Approximately 5\% of isolates gave the same lesion types for three independent observations (one on original pear bait, two on inoculated pears).

Morphological characterization. Only $15 \%$ of the isolates retrieved during the course of the study produced sporangia and oospores in numbers sufficient for positive identification. Seventynine isolates were identified as $P$. cactorum. Thirty-six isolates (including 1999 isolates 910, 928, 948, 954, and 964) were identified as $P$. citricola. Only two of the isolates produced papillate sporangia and, due to lack of oospore production, could not be identified to species. The remaining 634 isolates could not be identified by morphological criteria. These isolates had nonpapillate sporangia and were placed in Waterhouse groups V or VI. Two of the isolates with unique growth morphologies produced some paragynous antheridia and a few internally proliferous, nonpapillate sporangia. Although these two isolates had features characteristic of Waterhouse group $\mathrm{V}$, the observed morphological characteristics were insufficient for species identification. In 1999, 12 different growth types were observed among 180 isolates (Tables 2 and 3). The majority (85\%) of the isolates could be classified into growth types $1,2,3$, and 9 .

PCR-RFLP analysis of nuclear rDNA ITS. A PCR amplicon of 900 to $950 \mathrm{bp}$ was obtained for all 180 isolates during 1999 using the ITS1 and ITS4 universal primers (48). Variation was investigated using restriction enzyme digestion with three enzymes: MspI, RsaI, and HaeIII. A phenogram based on similarity of RFLP fragments revealed several clusters of isolates with low (50 to $65 \%$ ) bootstrap support. Two large clusters of isolates (labeled A and B) had bootstrap support greater than $80 \%$ (Fig. 2). All except one of the 180 isolates sampled from irrigation water in 1999 fell into cluster A with high bootstrap support (Fig. 2). Cluster A also included reference species $P$. lateralis, $P$. capsici, $P$. citricola, $P$. pseudostugae, $P$. cinnamomi, $P$. gonapodyides, $P$. parasitica (isolate 1), $P$. megasperma (isolate 1), and 179 isolates from irrigation water. Cluster B included $P$. palmivora, $P$. mirabilis, $P$. infestans, $P$. parasitica (isolate 2), $P$. megasperma (isolate 2 ), $P$. cactorum, and one sampled isolate (isolate 894). Multiple isolates of each reference species had the same PCR-RFLP haplotype and clustered together, except $P$. megasperma isolates 1 and 2 and $P$. parasitica isolates 1 and 2 (Fig. 2).
Phylogenetic analysis of nuclear rDNA ITS2. Fifty isolates from the 1999 sampling were selected for phylogenetic analysis based on growth type on CMA and PCR-RFLP analysis. Selected isolates included at least one representative of each RFLP pattern and each growth type. ITS2 regions of selected isolates and 14 isolates representing 12 reference Phytophthora spp. were amplified and amplicons of the expected size (590 to $620 \mathrm{bp}$ ) were obtained using ITS3 and ITS4 universal primers. ITS2 sequences examined in the phylogenetic analysis ranged from 561 to $583 \mathrm{bp}$ for sampled isolates and 558 to 583 bp for reference Phytophthora spp. Phylogenetic analysis revealed nine clades among the Phytophthora spp. retrieved from irrigation water, each with bootstrap support greater than $80 \%$ (Fig. 3). Clade 1 contained one isolate (871) and no reference species. Clade 2 included two isolates (857 and 969) and two reference species, P. cambivora (GeneBank Accession No. AF266763) and P. pseudotsugae. The third clade contained isolates 910,881 (representing five isolates with identical sequence), and 928 and reference species $P$. citricola and $P$. capsici. Clade 4 contained one isolate with papillate sporangia (isolate 894) and P. cactorum. Clade 5 contained isolates 776, 777 , and 829 and no reference species. BLAST searches revealed that the most similar sequences to these isolates were represented by $P$. gonapodyides, which formed another well-separated clade in our phylogram (clade 9). The sixth clade contained isolates 783 and 793, and clade 7 contained isolates 772 (representing five isolates with identical sequence), 812, 955, and 810 plus reference species $P$. parasitica. Clade 8 contained isolate 951 and no reference species, and clade 9 contained isolates 861, 808, 775 (repre-

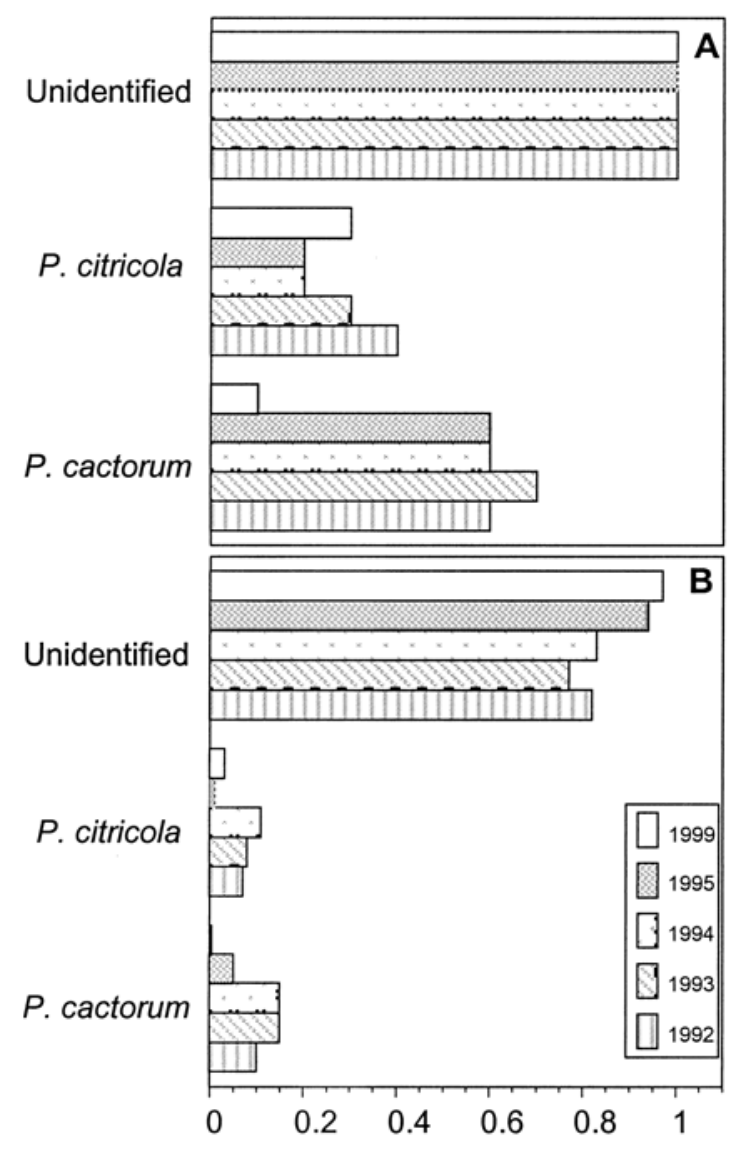

Proportion of canals/isolates

Fig. 1. A, Proportions of canals infested and B, Phytophthora spp. isolates retrieved and classified as $P$. cactorum, $P$. citricola, or unidentified nonpapillate species 1992 to 1995 and 1999. Isolates were obtained from irrigation canals in eastern Washington using immature pears as baits. 
senting 19 isolates with identical sequence), 923, and 784 and reference species $P$. megasperma and $P$. gonapodyides. All isolates producing sporangia in this clade had nonpapillate sporangia. $P$. gonapodyides had an ITS2 haplotype identical to the 19 isolates represented by isolate 775 .

The phenogram based on PCR-RFLP (Fig. 2) and the phylogram based on ITS2 sequences (Fig. 3) were not strictly correlated although they had similar topology. The level of resolution obtained with the ITS2 sequence data was much higher than that obtained with ITS-RFLP.

Comparison of morphological and molecular data. Colony morphology of all isolates was compared with PCR-RFLP and ITS2 sequence variation to detect possible correlations. Consistent correlation between colony morphology and ITS haplotype was observed in only three cases (Table 2). Colony morphologies 6, 14 , and 20 were consistently associated with ITS2 clades 2,4 , and 3 , respectively. The remainders of the colony morphologies were not consistently associated with ITS haplotype (Table 2). Isolates from four of seven PCR-RFLP clusters exhibited more than one growth type per haplotype. Conversely, the same growth types were observed for several different PCR-RFLP haplotypes.

\section{DISCUSSION}

During all years of the study, Phytophthora spp. pathogenic to pear were present in irrigation water beginning during the early stages of fruit development and susceptibility. There was temporal and spatial variability in initial occurrence and species composition of irrigation water, indicating that producers should assume that inoculum is present throughout the fruit development period and treat irrigation water accordingly. P. cactorum is considered the primary incitant of sprinkler rot of apple and pear, and was the predominant species in irrigation water during earlier studies (22). This species comprised only $10 \%$ of the isolates in this long-term study using conventional and modified pear baiting techniques. The nonpapillate isolates were spatially and temporally more prevalent in water and more frequently isolated when baits were suspended in jars. These isolates were present in all 10 of the irrigation canals sampled during 1992 to 1995 and were occasionally isolated from naturally infected fruit during sprinkler rot epidemics that occurred during the study period. However, infection of pears using our baiting technique does not necessarily indicate that all retrieved isolates could infect pears under orchard conditions. The role of the nonpapillate isolates in the etiology and epidemiology of sprinkler rot needs further study. Our results also indicate that the conventional method of suspending pears in irrigation canals for several days may be not be sensitive enough for the results to be used to time the initial copper treatment of irrigation water.

Irrigation water has been reported as a source of several Phytophthora spp. including $P$. capsici, $P$. cinnamomi, $P$. citricola, $P$. citrophthora, and $P$. parasitica (14). P. cactorum, which has been reported as the causal agent of sprinkler rot of pear and apple, was

TABLE 2. Relationships among clusters defined with internal transcribed spacer (ITS) polymerase chain reaction restriction fragment length polymorphism (PCR-RFLP) data, clades defined with ITS2 sequence data, and colony morphologies/growth types

\begin{tabular}{lcc}
\hline PCR-RFLP cluster $^{\mathrm{a}}$ & ITS2 $^{\text {clade }}$ & Colony morphology $^{\mathrm{c}}$ \\
\hline A & 4 & $1,3,4,5,18,19$ \\
B & 5 & $2,3,5,19$ \\
C & 5 & $1,2,9$ \\
D & 6 & 6 \\
D & 7 & $6,14,16$ \\
E & 2 & 14 \\
F & 1 & 20 \\
\hline
\end{tabular}

${ }^{a}$ Clusters defined based on bootstrap values greater than $75 \%$ (Fig. 1).

${ }^{b}$ Clades defined based on bootstrap values greater than $75 \%$ (Fig. 2).

${ }^{c}$ Colony morphology determined on corn meal agar. isolated from irrigation water in several earlier studies $(3,22,24)$, and was isolated 79 times during the course of this study. Over the 5 year study, 36 isolates from irrigation water were identified as $P$. citricola. $P$. citricola was previously found in irrigation water and recorded as pathogenic to apple roots (29). However, $P$. citricola has not been reported as an incitant of fruit rot of pear and apple, but has been occasionally isolated from naturally infected pear fruit in Washington State. This species therefore should be considered a hazard to developing fruit, particularly in orchards irrigated with water from contaminated canals or ponds.

Several morphologically distinct isolates were retrieved in 1999, but they could not be identified to species using conventional methods. Based on molecular analyses, the predominant species retrieved from irrigation water during the course of this study was $P$. gonapodyides. Nineteen of the 1999 isolates had identical ITS2 sequences to the reference species. Some of these isolates produced nonpapillate sporangia but no oospores and could not be positively identified. $P$. gonapodyides is a heterothallic species and requires both mating types for production of sexual propagules, which could account for the absence of oospores in our cultures $(14,38,41)$. Although $P$. gonapodyides has been reported as the causal organism of root rot diseases of several hosts, the first isolation of $P$. gonapodyides was performed from decaying apple fruit in 1910 (36). Phylogenetic analysis showed that there were several isolates from irrigation water that are not closely related to any described Phytophthora sp. It is possible that these isolates might represent new Phytophthora spp.

Phylogenetic analysis indicated that there were at least nine different phylogenetic taxa of Phytophthora in irrigation water. $P$. cactorum was infrequently isolated during the course of this study, but was isolated throughout the growing season in previous studies $(21,23)$. None of the 1999 isolates sampled from irrigation water were identified as $P$. cactorum based on morphological characteristics. Only one isolate (isolate 894) had a similar RFLP pattern and resided in the same clade with $P$. cactorum in the phylogram, strongly suggesting that it was $P$. cactorum. These results are in contrast with previous studies in which $P$. cactorum was the common Phytophthora sp. recovered from irrigation water in this geographical area $(21,23)$. All isolates obtained in the early studies were obtained by suspending pears in irrigation canals, whereas the majority of isolates obtained during the current study were isolated from pears suspended in irrigation water contained in jars in the laboratory. The use of the latter technique may add precision to investigations of the Phytophthora spp. composition of irrigation water.

In several studies, phylogenetic analysis of ITS sequences has not supported the differentiation of Phytophthora spp. based on papillal, antheridial, or thallic characteristics $(5,6,10)$. The grouping of semipapillate and papillate or semipapillate and nonpapillate species were frequently observed by several workers (5-

TABLE 3. Growth type of Phytophthora isolates on corn meal agar

\begin{tabular}{llc}
\hline Growth type & Characteristics of growth types & Number of isolates \\
\hline 1 & Segmented & 42 \\
2 & Radiating, shiny, irregular margin & 59 \\
3 & Radiating, smooth margin & 12 \\
6 & Lanceolate, petiolate & 2 \\
9 & Radiating, fine mycelium & 45 \\
14 & Fairly fluffy, not radiating, curly & 5 \\
15 & Weak growth, no pattern & 1 \\
16 & Fluffy, not radiating, curly & 1 \\
17 & Radiating, not shiny, not smooth & 4 \\
18 & Fairly fluffy, lanceolate & 1 \\
19 & Slightly fluffy, slightly curly & 6 \\
20 & Fast growth, no pattern & 5
\end{tabular}

${ }^{a}$ Isolates were retrieved from irrigation water using immature pear fruits as baits. Colonies were determined according to the classification system of Ribeiro (40). 
$8,16)$. In this study, grouping of $P$. mirabilis and $P$. infestans with semipapillate sporangia (group IV) and $P$. cactorum with papillate sporangia (Waterhouse group I) supported the results of previous studies. A similar situation was observed in clade 7 including some nonpapillate and papillate isolates and group II species $P$. parasitica. In addition, nonpapillate Waterhouse group VI species $P$. cambivora, five isolates from irrigation water (two of which produced nonpapillate sporangia), and Waterhouse group I species $P$. pseudotsugae were placed in the same clade. Although P. cambivora was recorded as pathogenic to apple and pear in previous studies (29), morphological characteristics were not sufficient to describe these five isolates as $P$. cambivora. Therefore, our results also suggest that Waterhouse groups do not represent a natural assemblage. However, this classification scheme has been a valuable tool for the identification of Phytophthora spp. prior to the advent of molecular techniques. Additional molecular studies evaluating different genomic regions are required for better resolution of the genus.

We observed different RFLP patterns among multiple isolates of $P$. parasitica and $P$. megasperma. RFLP patterns for ITS regions of $P$. megasperma $(17,39)$ and $P$. citrophthora (26) isolates were distinct (within species) in previous studies. Nuclear DNA analysis also showed intraspecific variation within $P$. megasper$m a, P$. palmivora, $P$. parasitica, $P$. capsici, and $P$. megakarya isolates (18).

Colony morphology has been characterized by various growth media. Corn meal, potato dextrose, and carrot agars have been suggested as the most useful media to detect distinct cultural patterns $(14,38)$. In this study, isolates were divided into 12 groups

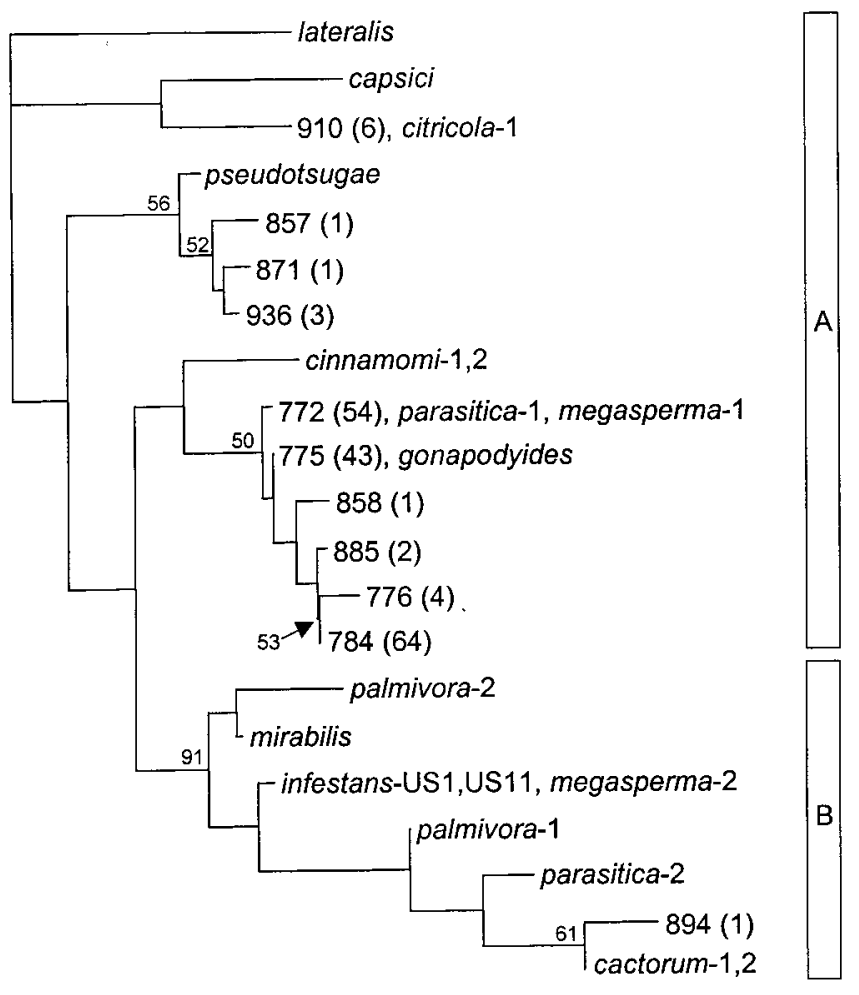

0.1

Fig. 2. Phenogram of genetic similarity among samples of Phytophthora spp. from irrigation water based on polymerase chain reaction restriction fragment length polymorphism (PCR-RFLP) of internal transcribed spacer region. Representative isolate numbers and reference species are indicated. Numbers in parentheses indicate the total number of isolates with identical PCR-RFLP haplotype. Numbers at the major branches indicate the percentage occurrence of the cluster to the right of the branch in 1,000 bootstrapped phenograms. Clusters containing sampled isolates with bootstrap values greater than $80 \%$ are labeled A and B. Scale represents 10\% differentiation. based on colony morphology on CMA. Our results indicated that isolates with different genotypes could be of similar growth type and vice-versa. Similar colony morphologies (clade 5 containing $P$. citricola and clade 3 with unique isolates) were observed in some clades, suggesting this criterion may be used as a distinguishing characteristic for some species. Although variation in colony morphology has been considered by a number of researchers to have limited utility for identification (14), the criterion has in some instances been used as a differentiating characteristic (41,44-46). However, it is not a consistent criterion for identification and should be used in conjunction with other characters.

The molecular data reported here suggest that revision in the taxonomy of Phytophthora is required. Although entire ITS

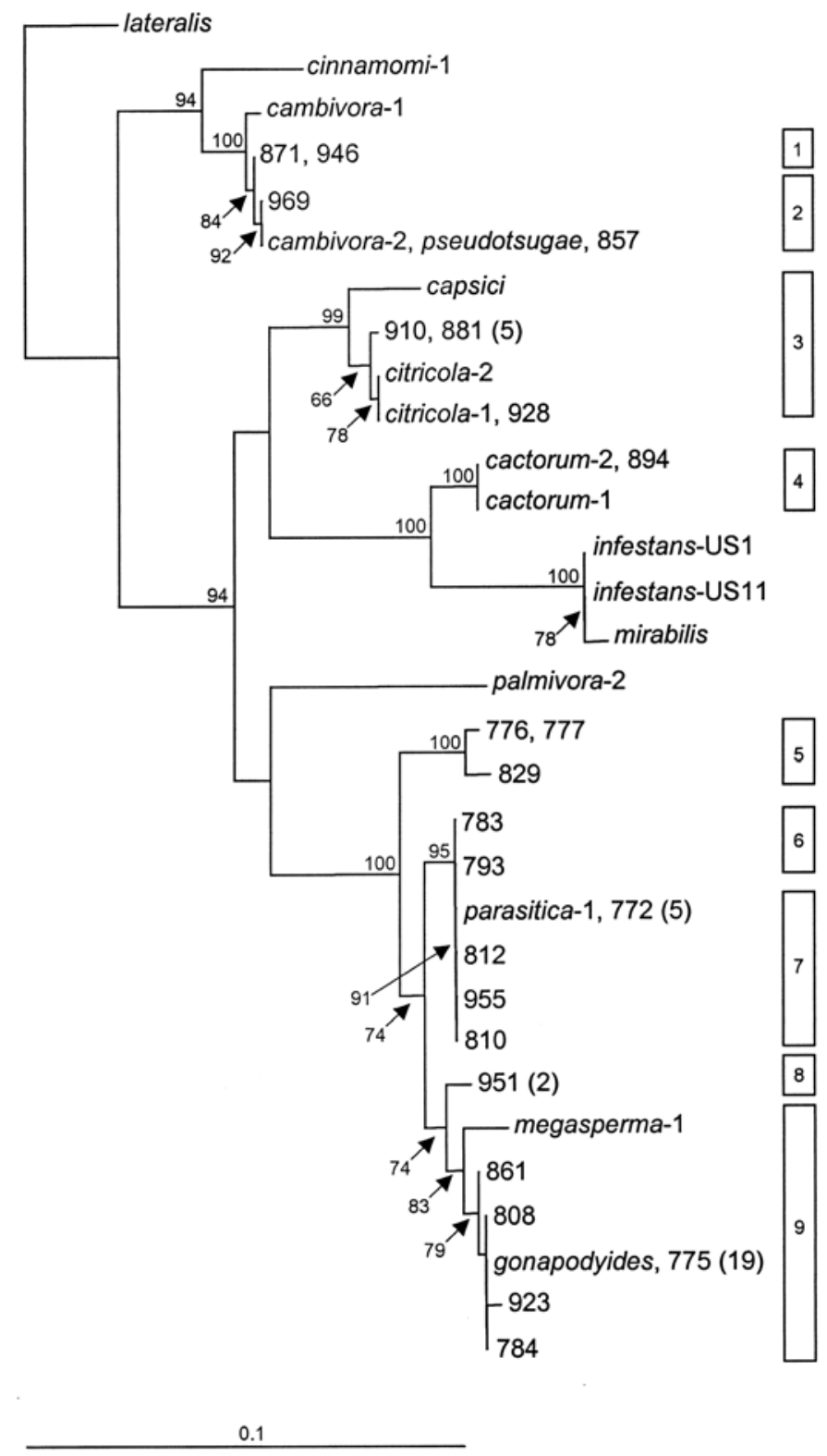

Fig. 3. Internal transcribed spacer 2 (ITS2) phylogeny estimated among Phytophthora spp. sampled from irrigation water using distance analysis and neighbor joining. Representative isolate numbers and reference species are indicated. Numbers in parentheses indicate the total number of isolates with identical ITS2 haplotype. Numbers at the major branches indicate the percentage occurrence of the cluster to the right of the branch in 1,000 bootstrapped phylograms. Clades with sampled isolates and bootstrap values greater than $80 \%$ are labeled 1 through 9. Branch separating clade 7 from clade 6 (91\% bootstrap support) is too short to be visible. Scale represents 0.1 nucleotide substitutions per site. 
regions of rDNA have been useful for reevaluation of the genus and other oomycete genera, this region is not always useful for species differentiation (8). Additional studies that evaluate different regions of the genome are needed $(5,8,10,17)$. Because morphological characters are required for accurate identification, studies on methods that promote sporulation in vitro would be useful.

\section{ACKNOWLEDGMENTS}

We thank the Washington State Tree Fruit Research Commission and the Agriculture Research Center, Washington State University, for the support of this research.

\section{LITERATURE CITED}

1. Brasier, C. M., Cooke, D. E. L., and Duncan, J. M. 1999. Origin of a new Phytophthora pathogen through interspecific hybridization. Proc. Natl. Acad. Sci. USA 96:5878-5883.

2. Braun, H., and Schwinn, F. J. 1963. Continued research on the incidence of collar rot of apple trees (Phytophthora cactorum). J. Phytopathol. 43:327-3704.

3. Browne, G. T. 1991. Prevalence, pathogenicity, and relative virulence of Phytophthora spp. in association with apple, and host resistance and seasonal susceptibility as factors that affect development and control of the disease. Ph.D. thesis. University of California, Davis.

4. Bruns, T. D., White, T. J., and Taylor, J. W. 1991. Fungal molecular systematics. Annu. Rev. Ecol. Syst. 22:525-564.

5. Cooke, D. E. L., and Duncan, J. M. 1997. Phylogenetic analysis of Phytophthora species based on ITS1 and 2 sequences of the rDNA gene repeat. Mycol. Res. 101:667-677.

6. Cooke, D. E. L., Jung, T., Williams, N. A., Schubert, R., Bahnweg, G., Ossward, W., and Duncan, J. M. 1999. Molecular evidence supports Phytophthora quercina as a distinct species. Mycol. Res. 103:799-804.

7. Cooke, D. E. L., Kennedy, D. M., Guy, D. C., Russell, J., Unkles, S. E., and Duncan, J. M. 1996. Relatedness of group I species of Phytophthora as assessed by randomly amplified polymorphic DNA (RAPDs) and sequences of ribosomal DNA. Mycol. Res. 100:297-303.

8. Cooke, L. R., Drenth, A., Duncan, J. M., Wagels, G., and Brasier, C. M. 2000. A molecular phylogeny of Phytophthora and related Oomycetes. Fungal Genet. Biol. 30:17-32.

9. Covey, R. P., and Harris, D. C. 1990. Phytophthora fruit rots of pear and apple. Pages 30-31 in: A Compendium of Apple and Pear Diseases. The American Phytopathological Society, St. Paul, MN.

10. Crawford, A. R., Bassam, B. J., Drenth, A., Maclean, D. J., and Irwin, J. A. G. 1996. Evolutionary relationships among Phytophthora species deduced from rDNA sequence analysis. Mycol. Res. 100:437-443.

11. Dick, M. W., Vick, M. C., Gibbing, J. G., Hedderson, T. A., and Lastra, C. C. L. 1999. 18S rDNA for species of Leptolegnia and other Peronosporomycetes: Justification for the subclass taxa Saprolegniomycetidae and Peronosporomycetidae and division of the Saprolegniaceae sensu lato into the Leptolegniaceae and Saprolegniaceae. Mycol. Res. 103: 1119-1125

12. Edel, V. 1998. Use of PCR and RFLP in fungal systematics. Pages 52-91 in: Chemical Fungal Taxonomy. J. C. Frishvad, P. D. Bridge, and D. K. Arora, eds. Marcel Dekker, New York.

13. Erwin, D. C., Bartnicki Garcia, S., and Tsao, P. H. 1983. Phytophthora: Its Biology, Taxonomy, Ecology, and Pathology. The American Phytopathological Society, St. Paul, MN.

14. Erwin, D. C., and Riberio, O. K. 1996. Phytophthora Diseases Worldwide. The American Phytopathological Society, St. Paul, MN.

15. Förster, H., and Coffey, M. D. 1993. Molecular taxonomy of Phytophthora megasperma based on mitochondrial and nuclear DNA polymorphisms. Mycol. Res. 97:1101-1112.

16. Förster, H., Cummings, M. P., and Coffey, M. D. 2000. Phylogenetic relationships of Phytophthora species based on ribosomal ITSI DNA sequence analysis with emphasis on Waterhouse groups V and VI. Mycol. Res. 104:1055-1061.

17. Förster, H., Learn, G., and Coffey, M. D. 1995. Towards a better understanding of the evolutionary history of species of the genus Phytophthora using isozyme, DNA RFLPs and ribosomal DNA spacer sequences. Pages 42-54 in: Phytophthora infestans 150. L. J. Dowley, E. Bannos, L. R. Cooke, T. Keane, and E. O'Sullivan, eds. Boole Press, Dublin, Ireland.

18. Förster, H., Oudemans, P., and Coffey, M. D. 1990. Mitochondrial and Nuclear DNA diversity within six species of Phytophthora. Exp. Mycol. 14:18-31.
19. Gardes, M., Fortin, J. A., Mueller, G. M., and Kropp, B. R. 1990. Restriction fragment length polymorphism in the nuclear ribosomal DNA of four Laccaria spp.: L. bicolor, L. laccata, L. proxima, and $L$. amethystina. Phytopathology 80:1312-1317.

20. Graham, J. H., Timmer, L. W., Drouillard, D. L., and Peever, T. L. 1998. Characterization of Phytophthora spp. causing outbreaks of citrus brown rot in Florida. Phytopathology 88:724-729.

21. Griffith, G. W., and Shaw, D. S. 1998. Polymorphisms in Phytophthora infestans: Four mitochondrial haplotypes are detected after PCR amplification of DNA from pure cultures or from host lesions. Appl. Environ. Microbiol. 64:4007-4014.

22. Grove, G. G., and Boal, R. J. 1991. Influence of temperature and wetness duration on infection of immature apple and pear fruit by Phytophthora cactorum. Phytopathology 81:1465-1471.

23. Hantula, J., Lilja, A., and Paricca, P. 1997. Genetic variation and host specificity of Phytophthora cactorum isolated in Europe. Mycol. Res. 101:565-572.

24. Hassan, N. M. M. B. H. N. 1987. Distribution and survival of Phytophthora cactorum in irrigated orchard soil in Washington. Ph.D. thesis. Washington State University, Pullman.

25. Lacourt, I., Panabieres, F., Marais, A., Venard, P., and Ricci, P. 1994. Intraspecific polymorphism of Phytophthora parasitica revealed by analysis of mitochondrial DNA restriction fragment length polymorphism. Mycol. Res. 98:562-568.

26. Lee, S. B., and Taylor, J. W. 1992. Phylogeny of five fungus-like protoctistan Phytophthora spp., inferred from the internal transcribed spacers of ribosomal DNA. Mol. Biol. Evol. 9:636-653.

27. Man in't Veld, W. A., Veenbaas-Rijks, W. J., Ilieva, E., de Cock, A. W. A. M., Bonants, P. J. M., and Pieters, R. 1998. Natural hybrids of Phytophthora nicotiana and Phytophthora cactorum demonstrated by isozyme analysis and random amplified polymorphic DNA. Phytopathology 88: 922-929.

28. Maufrand, R., Archer, S. A., Buck, K. W., Shaw, D. S., and Shattock, R. C. 1995. The use of RAPD markers in genetic studies of Phytophthora infestans. Pages 42-54 in: Phytophthora infestans 150. L. J. Dowley, E. Bannos, L. R. Cooke, T. Keane, and E. O'Sullivan, eds. Boole Press, Dublin, Ireland.

29. McIntosh, D. L. 1966. The occurrence of Phytophthora spp. in irrigation systems in British Colombia. Can. J. Bot. 44:1591-1596.

30. Miller, P. M. 1955. V-8 juice agar as a general purpose medium for fungi and bacteria. Phytopathology 45:461-462.

31. Newhook, F. J., Waterhouse, G. M., and Stamps, D. J. 1978. Tabular key to the species of Phytophthora de Bary. Mycol. Pap. 143. Commonw. Mycol. Inst., Kew, UK.

32. Oudemans, P., and Coffey, M. D. 1991. Isozyme comparison within and among worldwide sources of three morphological distinct species of Phytophthora. Mycol. Res. 95:19-30.

33. Oudemans, P., and Coffey, M. D. 1991. A revised systematics of twelve papillate Phytophthora species based on isozyme analysis. Mycol. Res. 95:1025-1046.

34. Page, R. D. M. 1996. TREEVIEW: An application to display phylogenetic trees on personal computers. Comput. Appl. Biosci. 12:357-358.

35. Peever, T. L., Canihos, Y., Olsen, L., Ibañez, A., Liu, Y.-C., and Timmer, L. W. 1999. Population genetic structure and host specificity of Alternaria spp. causing brown spot of Minneola tangelo and rough lemon in Florida. Phytopathology 89:851-860.

36. Petersen, H. E. 1910. An account of Danish freshwater-Phycomycetes with biological and systematical remarks. Ann. Mycol. 8:494-560.

37. Reithmüller, A., Weiß, M., and Oberwinkler, F. 1999. Phylogenetic studies of Saprolegniomycetidae and related groups based on nuclear large subunit ribosomal DNA sequences. Can. J. Bot. 77:1790-1800.

38. Ribeiro, O. K. 1978. A Source Book of the Genus Phytophthora. Strauss \& Cramer, Hirschberg, Germany.

39. Ristaino, J. B., Madritch, M., Trout, C. L., and Parra, G. 1998. PCR amplification of ribosomal DNA for species identification in the plant pathogen genus Phytophthora. Appl. Environ. Microbiol. 64:948954.

40. Schmitthenner, A. F. 1973. Isolation and identification methods for Phytophthora and Pythium. Pages 94-110 in: Proc. First Woody Ornamental Dis. Workshop. University of Missouri, Colombia.

41. Stamps, D. J., Waterhouse, G. M., Newhook, F. J., and Hall, G. S. 1990. Revised tabular key to the species of Phytophthora. Mycol. Pap. 112. Commonw. Mycol. Inst., Kew, UK.

42. Thompson, J. D., Gibson, T. J., Plewniak, F., Jeanmougin, F., and Higgins, D. G. 1997. The ClustalX windows interface: Flexible strategies for multiple sequence alignment aided by quality analysis tools. Nucleic Acids Res. 24:4876-4882.

43. Tooley, P. W., Carras, M. M., and Falkenstein, K. F. 1996. Relationship among group IV Phytophthora species inferred by restriction analysis of 
the ITS2 region. J. Phytopathol. 144:363-369.

44. Waterhouse, G. M. 1963. Key to the species of Phytophthora de Bary. Mycol. Pap. 92. Commonw. Mycol. Inst., Kew, UK.

45. Waterhouse, G. M. 1970. Taxonomy in Phytophthora. Phytopathology 60:1141-1143.

46. Waterhouse, G. M., Newhook, F. J., and Stamps, D. J. 1983. Present criteria for classification of Phytophthora. Pages 139-148 in: Phytophthora: Its Biology, Taxonomy, Ecology, and Pathology. D. C. Erwin, S. Bartnicki Garcia, and P. H. Tsao, eds. The American Phytopathological
Society, St. Paul, MN.

47. Wernham, C. C. 1946. Mineral oil as a fungus culture preservation. Mycologia 38:691-692.

48. White, T. J., Bruns, T., Lee, S., and Taylor, J. 1990. Amplification and direct sequencing of fungal ribosomal RNA genes for phylogenetics. Pages 315-322 in: PCR Protocols. M. A. Innis, D. H. Gelfand, J. J. Sninky, and T. J. White, eds. Academic Press, San Diego.

49. Zentmeyer, G. A., and Marshal, L. A. 1959. Factors effecting sporangial production by Phytophthora cinnamomi. Phytopathology 49:556. 